University of Nebraska - Lincoln

DigitalCommons@University of Nebraska - Lincoln

University of Nebraska Press -- Sample Books

and Chapters

University of Nebraska Press

2012

Colorado Politics and Policy

Thomas E. Cronin

Robert D. Loevy

Follow this and additional works at: https://digitalcommons.unl.edu/unpresssamples

Part of the Arts and Humanities Commons

Cronin, Thomas E. and Loevy, Robert D., "Colorado Politics and Policy" (2012). University of Nebraska Press -- Sample Books and Chapters. 121.

https://digitalcommons.unl.edu/unpresssamples/121

This Article is brought to you for free and open access by the University of Nebraska Press at DigitalCommons@University of Nebraska - Lincoln. It has been accepted for inclusion in University of Nebraska Press -- Sample Books and Chapters by an authorized administrator of DigitalCommons@University of Nebraska - Lincoln. 
COLORADO POLITICS AND POLICY 


\section{Politics and Governments}

of the American States

Founding Editor

Daniel J. Elazar

Published by the University of

Nebraska Press in association

with the Center for the Study of

Federalism at the Robert B.

and Helen S. Meyner Center

for the Study of State and Local

Government, Lafayette College 


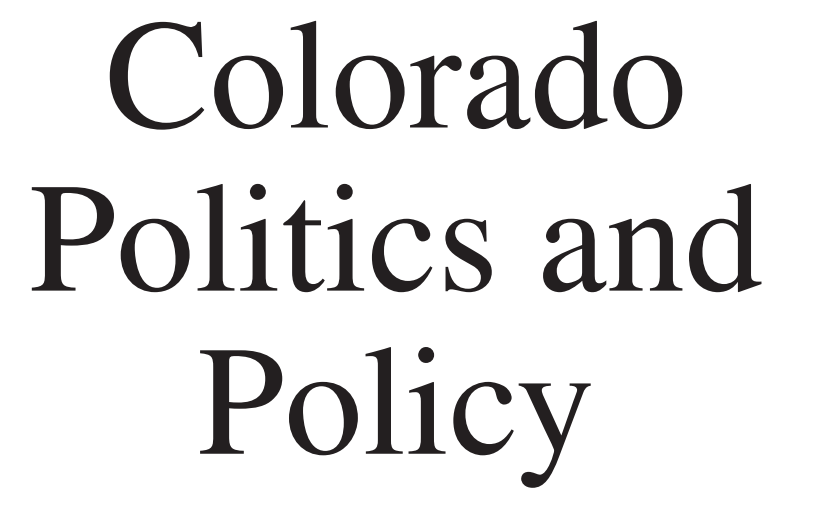

GOVERNING A PURPLE STATE

UNIVERSITY OF NEBRASKA PRESS

LINCOLN AND LONDON 
(C) 2012 by Thomas E. Cronin and Robert D. Loevy

All rights reserved

Manufactured in the United States of America

(2)

Library of Congress Cataloging-in-Publication Data

Cronin, Thomas E.

Colorado politics and policy: governing a purple

state / Thomas E. Cronin and Robert D. Loevy.

p. cm.-(Politics and governments of the

American states)

Includes bibliographical references and index.

Rev. and expanded ed. of: Colorado politics \&

government. cI993.

ISBN 978-0-8032-4074-2 (pbk.: alk. paper)

I. Colorado-Politics and government-I95I-

I. Loevy, Robert D., I935- II. Cronin, Thomas E.

Colorado politics \& government. III. Title.

JK78I 6. C77 20 I 2

$320.9788-\mathrm{dc} 23$

2012008246 
In loving memory of

Constance Loevy, and to our long,

wonderful friendship with Jerry and Anabel McHugh 
List of Tables, Maps, and Figures, ix Preface, xi

Acknowledgments, Xv

ONE

The Character and Spirit of Colorado, I

TWO

Coloradans and Their Political Beliefs, 36

THREE

A Brief Sociopolitical History of Colorado, 77

FOUR

The Colorado Constitution and Its Politics, 95

FIVE

Political Parties and Elections in Colorado, I22

SIX

Electing Colorado Legislators, I46

SEVEN

Legislative Politics and Processes, I67

EIGHT

The Colorado Governorship, I95

NINE

Judges and Justice in Colorado, 235 
TEN

Colorado in the Federal System, 270

ELEVEN

The Important Role of Local Government, 295

TWELVE

Colorado's Assets and Liabilities, 320

Notes, 363

Suggestions for Further Research, 385

Selected Bibliography, 387

Index, 395 
TABLES

I. Recent and Future Demographic Trends, 39

2. Is Colorado Going in Right/Wrong Direction?, 43

3. Populist Initiatives-Right and Left, 49

4. Colorado's Political Landscape, 55

5. Government Role in Discrimination, 6o

6. Environmentalism, 70

7. Creationists versus Evolutionists, 74

8. Political Outlook of Coloradans, I32

9. Women in the Colorado State Legislature, I69

Io. Colorado Legislative Committees, I77

I I. Departments of Colorado State Government, 2 IO

I 2. Colorado's Twenty Most-Populous Cities, 302

I3. Colorado's Twenty Most-Populous Counties, 306

MAPS

I. Colorado's Predominant Population Center, 8

2. Major Rivers of Colorado, Io

3. Six Geographical Regions of Colorado, I 8

4. Republican, Democratic, and Swing Counties, I38

5. Gubernatorial Vote in 20IO, I43

6. Income Inequality, 350 
I. Coloradans' Assessments of State Government, 44 2. Trust in State Government, 45

3. Efficiency of Levels of Government, 47

4. Coloradans on the Role of the U.S. Government, 48

5. Making Referendums and Initiatives More Difficult, 5I

6. Do Big Campaign Contributors Run State Government?, 52

7. Conservative, Middle-of-the-Road, or Liberal?, 54

8. Liberty vs. Equality, 59

9. Coloradans and Their Party Loyalties, 64

Io. Coloradans' Party Ties and Differences, 66-67

I I. Partisan Views on Liberty and Equality, I3 I

I2. Approval/Disapproval of State Legislature, I47

I3. Comparing Colorado State General Fund Budgets, 33 I 


\section{Preface}

Colorado has a proud history of being a fiercely independent frontier state. Yet in reality Colorado is largely urbanized. Ninety percent or more of the residents live along the state's two main interstate highways, I-25 and I-70.

Coloradans (it is not Coloradoans) express decidedly negative attitudes toward the U.S. government. The citizen surveys conducted for this book reveal that most Coloradans think the "feds" are too big, too wasteful, and too intrusive. Yet Colorado would be economically devastated if federal installations suddenly left the state and federal contracts and subsidies for a variety of activities and services were ended.

Imagine, for example, a Colorado Springs without the U.S. Army base at Fort Carson, the U.S. Space Command, or the U.S. Air Force Academy. Imagine the Boulder-Golden area without its several national research laboratories. Imagine if Colorado's national forests, parks, and monuments or U.S. Bureau of Land Management lands were privatized.

Coloradans, to be sure, favor a much smaller federal government, but they do not favor the elimination of major U.S. government projects and spending programs in Colorado.

Colorado, in fact, has been uncommonly dependent on the federal government to help manage its mountains and forests, develop its mineral and water resources, build its interstate highways and airports, and provide its human services.

Colorado has a proud history of being fiscally prudent. The state is known for its balanced budgets, low state taxes, and relatively low debt. Most Coloradans are skeptical about government and object to expanding taxing and spending powers. The objections to higher taxes can, however, be overcome when the tax pays for a service that voters like, such as buying open space or furthering historic preservation. 
But because of the generally low tax structure, many people believe the state electorate is shirking its responsibility to make critically needed investments for the state's future. Governor John Hickenlooper liked to say that Coloradans have to redefine the role of government to match what the people of the state can afford. In Colorado, this means taxpayer resistance to needed tax increases is a serious brake on state government.

Even incremental policy making in Colorado is a challenge. The state constitution is the third longest in the United States. It deliberately disperses power among different institutions, provides multiple veto opportunities, and sets up various checks and balances. It is much easier in Colorado to defeat new initiatives than to enact them. Divided government has become the new normal. Polarization between and within the two major political parties has grown.

Governmental authority in Colorado is intentionally limited, personal liberty is cherished, private-sector interests are both organized and strong, and political preferences are divided and sometimes shifting. In the surveys for this book, Coloradans said they believe government responds more to "insiders," special interests, and big campaign contributors than to the interests of the average person. Yet on many public policy issues, no single group or political party has a clear or consistent majority.

Over the past generation, Colorado has gradually shifted from being a somewhat "red," meaning Republican, state to becoming a fairly predictable "purple" state in its partisanship leanings. This has been the case both within the state and its electoral patterns, as within the nation. Colorado is often now a battleground or swing state. In statistical terms, Colorado in recent years is right in the middle (ranked 24 or 25 ) in the nation in its partisanship voting patterns. It does not get more purple than that. We discuss this more in chapter 5 .

So who governs Colorado? We are a state without much "old money," with few corporate headquarters, and with less of a defined "establishment" than most states. Can anyone, or any group, lead without political power? Does an increase in governmental authority necessarily mean a diminution of personal liberty?

What will it take to solve the Centennial State's economic problems? What will be required to plan for future growth and to preserve the state's beautiful lands and plentiful resources? What is the proper balance in the financing of economic development, job creation, education, and environmental protection? Can economic development and prudent conservation be done in a harmonious way? How will Colorado handle a doubling of its population over the next fifty to sixty years? 
How has a shifting electorate influenced politics in Colorado? And what of the much-debated and now more regularly used citizen-initiative process, where citizens sign petitions to put new laws and state constitutional amendments up for approval by the voters? Has it helped or handicapped public policy making in Colorado? How has this shaped, or reshaped, Colorado's political culture?

Colorado's assets are impressive, yet its challenges are daunting. Inequality is increasing in terms of both social class and geographical location. There is an ever-widening gap between poor counties and rich counties. Colorado's water supplies are overappropriated and understored. The state's highways and road bridges are in rough shape. The state's planning and budget process is unusually complicated and often counterproductive. The list goes on and on.

This book examines how politics and government work in Colorado. It represents an attempt to capture the spirit and distinctive politics that shape parties, elections, and public policy debates.

Our study of Colorado politics was encouraged by the late Professor Daniel Elazar, a respected political scientist at Temple University in Philadelphia. At his invitation, we wrote an earlier book on Colorado politics, published in 1993, which was part of a valuable series on state government in the United States that Elazar edited for the University of Nebraska Press. Each volume in that series examined the specific character of a state's "polity," defined as its political culture, traditions, and practices. Also studied were each state's constitution, governmental institutions, political constituencies, and interest groups.

So much has changed in Colorado politics and government in the past two decades that a new book was needed. For this book, we surveyed and interviewed hundreds of Colorado voters and scores of public officials, political analysts, lobbyists, and state employees. We conducted two statewide public opinion polls that followed up on a survey we did in I990. In the end, we had to rewrite nearly every part of our earlier work.

We thank those whose writings educated us, and we thank all those who have shared their views about the state and its politics. Please see our acknowledgments and selected bibliography. Views and interpretations in this book are, of course, wholly ours. 


\section{Acknowledgments}

We thank hundreds of people who have shared their views with us about Colorado politics, public policies, and government. Sometimes these were brief encounters in cafes or general stores in Holly, San Luis, Salida, Creede, Crestone, Crawford, Durango, Aspen, or Meeker. At other times they were at statewide meetings such as party conventions or the Colorado Water Congress.

But we have also conducted many lengthy interviews with state legislators, lobbyists, judges, the Colorado attorney general, and others. We helped run a several-hour forum with three former Colorado governors. We have gone to state of the state addresses, inaugurations, and sat in on sessions of the Colorado state supreme court and the Colorado Forum.

In addition, we have served on city planning commissions, city charter commissions, county storm-drainage committees, and the 20 I I Colorado Reapportionment Commission. We have served as precinct committee members, served on state party executive committees, attended state and national party conventions as elected delegates, and we have managed election campaigns both for candidates and for ballot issues, such as park bonds and building performing arts centers. Both of us have been involved in electoral politics at all levels.

We have traveled extensively around the state, and we have benefited from three statewide public opinion surveys of randomly selected adult Coloradans. These are surveys we designed and raised the funds for.

Among those we especially want to thank are governors Richard Lamm, Roy Romer, Bill Owens, Bill Ritter, and John Hickenlooper; Lieutenant Governor Joe Garcia; Attorney General John Suthers; U.S. senators Floyd Haskell, Gary Hart, Bill Armstrong, Tim Wirth, Ben Nighthorse Campbell, and Michael Bennet; U.S. Court of Appeals Judge Timothy M. Tymkovich; justices Rebecca Love Kourlis, Jean Dubofsky, Luis Rovira, Joseph Quinn, 
and Greg Hobbs; judges John Gallagher and Rebecca Bromley; state legislators Josh Penry, John Morse, Michael Bird, Chuck Berry, Ralph Cole, Terry Considine, Renny Fagan, Marcy Morrison, Peggy Kerns, Hugh Fowler, Wayne Knox, and Jana Mendez; mayors Federico Pena, Bill Sterling, Linda Shaw, Robert Isaac, and Mary Lou Makepeace; historians Duane Smith, Robert Smith, Patricia Limerick, and Marshall Sprague; newspaper reporters and columnists Bob Ewegen, Fred Brown, Vincent Carroll, Bruce Finley, Tim Hoover, Chuck Green, Charles Roos, Carl Miller, Carl Hilliard, and Ed Quillen; lobbyists and policy advocates Steve Durham, Gail Klapper, Dan Ritchie, Ed Bowditch, Ken Smith, Wade Buchanan, Mark Neuman-Lee, Adam Kretz, Stanley Dempsey, Briggs Gamblin, Pat Ratliff, and Roger Walton; political analysts Floyd Ciruli, Eric Sondermann, Katy Atkinson, Walt Klein, and Bob Drake; political scientists John Straayer and Seth Masket; state public employees Sharon Eubanks, Bob Lackner, Geoff Withers, Susanna Lienhard, Larry Kallenberger, Stewart Bliss, B. J. Thornberry, Eugene Petrone, Jim Westkott, Elizabeth Garner, Bill Porter, Douglas Brown, Todd Saliman, Michael Shea, Craig Welling, Mark Noel, John Stulp, Eddie Hunsinger, Cindy Degroen, John Ziegler, Reeves Brown, Bill Campbell, Jon Sarche, and Katharine Sanguinetti.

We also have been helped by John Andrews, Timothy Egan, Tad Foster, Thad Beyle, Janet Suthers, Jim Carpenter, Alan Salazar, Tom Clark, Bill Hybl, Kyle Hybl, John Weiss, John Hopper, Sean Paige, Armanda Arthur, Larry Deremo, Daniel Johnson, Bill Hochman, Dick Celeste, Walt Hecox, Jack Elder, and Jenn Sides.

Special thanks to Ed Bowditch, Jim Carpenter, Fred Brown, Bob Drake, Gail Klapper, Duane Smith, and John Straayer for their reading of the prepublication manuscript.

We especially thank Jerry and Anabel McHugh of Denver for their longterm encouragement, friendship, and financial support. We thank our colleagues at Colorado College, and particularly the librarians at Tutt Library, for their help and encouragement.

Research assistants at Colorado College who have helped on this and earlier writings on Colorado politics include John Calhoun, Walter Keller, Michael Shaver, Michael Trevithick, Amy Steinhoff, Alex Truax, Ben Taber, and Joe Jammal.

We are very grateful to copyeditor Lona Dearmont for greatly improving this book. We thank University of Nebraska Press editor Rob Taylor and editorial assistant Courtney Ochsner and all their colleagues for their valuable help.

All the above have helped make this a better, more-informed book, yet we assume responsibility for what is written. 